\title{
Illuminating nature and Gender Trouble in Zora Neale Hurston's Their Eyes Were Watching God
}

\author{
Sepideh Hozhabrossadat \\ Shahid Chamran University, Ahvaz, Iran \\ E-mail: Sepideh_hozhabrossadat@yahoo.com
}

Received: 18-01- 2015

Published: 01-09- 2015
Accepted: 02-04- 2015

Advance Access Published: April 2015

doi:10.7575/aiac.ijalel.v.4n.5p.124 URL: http://dx.doi.org/10.7575/aiac.ijalel.v.4n.5p.124

\begin{abstract}
In this article, the writer tries to map the structures of gender based on physical nature. Their Eyes Were Watching God is partly an objection and Hurston's protest to injustices in terms of gender bias toward Afro-American women of the late $19^{\text {th }}$ and early $20^{\text {th }}$ century. Here, the writer wants to pose a question and finds the answer whether Janie Crawford adheres to the fixed concept of gender or she does question it. Is there any sign in the novel to indicate that she breaks the rule and constructs herself and her identity not according to the structures of power in society but as an autonomous being who is conscious of her gender? This is achieved in terms of nature analysis.
\end{abstract}

Keywords: gender, nature, difference, body, growth, sexuality, fertility, death, birth

\section{Introduction}

In Their Eyes, Janie Crawford is the protagonist and to map her journey we need to notice her gender and how her sexuality affected her consciousness, identity, and worldview. First of all, we need to know more about gender and specifically gender as depicted in an all black community in a patriarchal society. Gender is an important base and issue in a patriarchal society, since a patriarchal society depends on creating persons and engendering them. ${ }^{1}$

The eminent French feminist, Simon de Beauvoire made this concept easier when she verbalized gender in the sense that one is not born but rather becomes a woman. People construct themselves as masculine or feminine and this happens due to both internal and external factors. Gender is a cultural term in which it explains the difference between women and men in culture, based on their biological difference. ${ }^{2}$ In Their Eyes, we as readers, become immediately conscious of what we are going to experience throughout the novel. Hurston warns us that this is a story about a woman: "Now, women forget all those things they don't want to remember, and remember everything they don't want to forget." ${ }^{3}$

This sentence comes at the beginning of the novel and in the following pages we have a picture in front of us in which Janie is being talked about and watched by men and women in diverse ways. Based on the first few pages we witness a kind of dichotomy between male and female in the society and we notice this difference mainly concerned with bodies. Feminism tries to modify this strict dichotomy by articulating the concept of gender as a social structure. In this social structure, our bodies are treated concerning their continuity, movement, and their actions. The concept of gender deals directly with our personal lives and the lifestyle of the community in which we live.

To become aware of gender means recognizing that men and women are not valued equally, that in fact, there exists more respect in the society for men. Being engendered, therefore, entails a coming to awareness of internalizing asymmetries of power and esteem.

As Janie comes back to Eatonville, men and women or better to say the porch talkers, get ready to shoot their most vile glances at her and her body: "What she doin coming back here in dem overalls? Cant she find no dress to put on? where's dat blue satin dress she left here in? - what dat ole forty year ole 'oman doin' wid her hair swingin' down her back lak some young gal?" (TE, 2)

Gender appears to remain unchanging and unwavering on the surface, because it is supported and reproduced by power structures in the society; but, individual's practices may shatter these structures and recreate the concept and shape of gender. Janie is totally under the spell of powerful structure in her society, but she changes herself, and as a result changes the fixed concept of gender.

\footnotetext{
${ }^{1}$ Deborah L. Madsen, Feminist Theory and Literary Practice (London: Pluto Press, 2000) 113.

${ }^{2}$ Raewyn Connel, Gender; Short Introductions (Cambridge: Polity Press, 2009) 9.

${ }^{3}$ Zora Neale Hurston, Their Eyes Were Watching God (New York: Perennial Classics, 1990) 1. Hereafter referred to as Their Eyes and in parentheses as TE followed by page number.
} 
Gender theories explore ideological inscription and literary effects of "the sex/gender system: 'that set of arrangements by which the biological raw material of human sex and procreation is shaped by human social intervention."'4

Connell in his groundbreaking book explains the origins of gender theories ${ }^{5}$ and the theorists behind them. Alfred Adler, the first major follower of Freud is named to be the first one who explicitly supports feminists and besides, he shows that categories of gender are not fixed from the start of life. Simon de Beauvoir shows that women are situated as 'other' in the consciousness of men. In her opinion, gender is a wholly arbitrary construction. In 1990, Judith Butler influenced the academia by her text, Gender Trouble. ${ }^{6}$ In this book she contends that there are no fixed foundations of gender categories. She believes there is no need to mobilize around a specific identity but rather it is needed to subvert the identity and to displace gender norms in a society. This is what Janie does in her community. She disrupts gender dichotomy by learning to play checkers, learning to shoot, to go fishing, to dress as she likes and many other examples which will be shown in this study.

Although these movements were pioneering and influential in breaking the fixed norms in a patriarchal society, it was not yet complete. These theorists mainly talked about gender without considering race or class. Black feminists reminded the other feminists, the realities of racism. bell hooks for instance, tried to integrate gender with race and class. New philosophical treaties were yet to come and finally it was agreed upon that gender was not fixed but fluid as was identity. The aim here is not to mention every individual theory on gender, but rather to give a short introduction to have a better understanding of the novel.

Here, I want to pose a question whether Janie Crawford adheres to the fixed concept of gender or she does question it. Is there any sign in the novel to indicate that she breaks the rule and constructs herself and her identity not according to the structures of power in society but as a speaking being to use Kristeva's term? ${ }^{7}$ To answer this question, we may map Janie's journey through life in terms of her gender and its relation to the surrounding. Janie encounters four important issues in her life. Nature is the background of her growth. We will go over this journey in terms of the relationship between gender and nature, and by nature I mean the physical nature.

\section{Nature}

Chapter two of the book contains much identification with nature, especially the image of the pear tree. Janie becomes conscious of her sexuality while she is under a blossoming pear tree. Tiny bloom, barren brown stem and glistening leaf-buds awaken the sense of existence in Janie. The first signs of growing love in Janie are apparent in nature. She grasps the notion of marriage in this important revelation:

She was stretched on her back beneath the pear tree soaking in the alto chant of the visiting bees, the gold of the sun and the panting breath of the breeze when the inaudible voice of it all came to her. She saw a dustbearing bee sink into the sanctum of a bloom; the thousand sister-calyxes arch to meet the love embrace and the ecstatic shiver of the tree from root to tiniest branch creaming in every blossom and frothing with delight. So this was a marriage! She had been summoned to behold a revelation. (TE, 11)

This passage is so illuminating about Janie, and her future concept regarding marriage. She watches the union between the bee and the blossom as the pear tree's response to this romantic action and she gets this message that beyond the sole concept of marriage, happiness and completeness exists. This is a secret that Janie watches and must heed during her life. ${ }^{8}$

In chapter two of the novel, these images of nature recur again and again to indicate the peaceful relationship between Janie and the natural environment. Janie is not hostile toward her physical nature, but rather she embraces it. She takes pleasure in flies "tumbling and singing, marrying and giving in marriage." She says: "Oh to be a pear tree-any tree in bloom! With kissing bees singing of the beginning of the world! (TE, 11)

It's not just Janie, who identifies herself with nature. Nanny, Janie's grandmother, associates herself and the slave women to the elements of nature. She tells Janie: "You know, honey, us colored folks is branches without roots and that makes things come round in queer ways. You in particular. Ah was born back due in slavery so it wasn't for me to fulfill my dreams of whut a woman oughta be and to do. Dat's one of de hold-backs of slavery. "(TE, 16)

As is clear from the comments, Janie has a positive outlook about nature from the beginning, but Nanny, on the other hand, depicts a negative view. The reason behind this negative concept is sufferings which have befell on the Nanny. For Nanny, the branches are without roots. The Nanny's views are destructive for what Janie feels about the pear tree.

\footnotetext{
${ }^{4}$ Sandra Kemp, and Judith Squires, ed. Feminisms (New York: OUP, 1997) 229. Showalter believes that, "gender is used to mean the social, cultural, and psychological constructs imposed upon biological sexual difference.”229.

${ }^{5}$ See Also David Glover and Cora Kaplan, Genders (New York: Routledge, 2000) 155.

${ }^{6}$ Judith Butler, Gender Trouble: Feminism and the Subversion of Identity (New York: Routledge, 1999).

${ }^{7}$ Noëlle McAfee, Julia Kristeva (New York: Routledge, 2004) 1.

${ }^{8}$ Vivi J. Dabee, The Summons to Behold a Revelation: Femininity and Foliage in Zora Neale Hurston's Their Eyes

Were Watching God, diss., The University of Manitoba, 2008 (Canada: 2008) 10.
} 
Nanny, because of the imposed ideology on slave women, thinks that she should not fulfill her dreams. She feels she is exploited and there is no way to redeem her race and her identity. ${ }^{9}$

Nanny had been a slave and though she identifies some aspects of her life and personality to elements in the nature, these identifications are not encouraging. She has endured hardships and her experience regarding nature is not a constructive one. She was a slave; she has been made to work on the lands. She narrates a bitter incident regarding her fly from the land she was a slave in:" In de black dark Ah wrapped mah baby de best Ah knowed how and made it to de swamp by de river. Ah knowed de place was full uh moccasins and other bitin' snakes, but Ah was more skeered Uh whut was behind me. "(TE, 18)

She talks of the noise of owls and how they scared her and also depicts trees and moving and crawling as if they wanted to haunt her and her baby and panthers prowling about. With all her hardships she suffered, her daughter turns out to be impregnated by her school teacher among nature. Nanny cannot risk letting Janie be on her own and her fantasies lead her away toward another catastrophe. So she decides to marry her off to Logan Killicks. When Janie confronts this forced marriage, she finds refuge under the pear tree while thinking about her fantasies and her expectations. She does not know whether she will find the love she experienced under the pear tree by marrying Logan or not. Although Nanny makes no sense of what Janie wants from marriage, she assures Janie that she will be prosperous and happy with Logan. So, Janie waited for a "bloom time, and a green time and an orange time." (TE, 25) Notice how expressive is the figurative language. Janie waits for love to bloom for her and to feel the sensation again. She waits for time to bring her happiness and flowering, but that does not happen.

In effect, Janie experiences a different sort of feeling in her marriage compared to what she experiences under the pear tree. This marriage brings suffering for her. She feels no true connection to Logan. She does not feel the positive image of nature in this marriage, but rather she experiences what Nanny warns about: branches without roots, as if she is hovering in a strange world. She is cut from her ideal world of nature and forced into a bitter rootless one, but she is still hopeful.

She knows things nobody told her about like the language of the trees. She speaks to the fallen seeds as if they are human beings. Somehow, we can suggest that Janie here wishes for the seeds the same thing that she wishes for her to happen. We know that seeds represent fertility. She often speaks to falling seeds," Ah hope you fall on soft ground," because she has heard seeds saying that to each other as they passed." (TE, 25)

This seed image is very important. When we see the end of the novel, when Janie returns from the Everglades, she leaves everything behind except a packet of seeds in remembrance of Tea Cake. On the surface, it shows that Janie likes nature, but deeper we see this act as a continuation of fertility and growth. Further, I will explain that this fertility is not limited in the nature; rather Janie becomes one with nature.

Basically Nanny and Janie think and see differently. What Nanny sees as love is very different from her granddaughter's opinion about love and sex. Nanny marries Janie off to Logan to protect her from what happened to herself and her daughter, Leafy. She thinks that women, especially black women, are leaves without roots. There is no place in Nanny's mind for growth and advancement of her own kind. Nanny thinks that black women in particular are loose in the sense that they are attached to no roots ${ }^{10}$ at all. So in her opinion they should not ask nature and wish anything, they should try to survive.

Janie is shown in the novel to become a woman the moment her first dream is dead. Her spiritual vision of marriage was the only thing she expected to happen while living with Logan. Janie becomes the mule of the world, the same thing that Nanny so feared to happen to her. The marriage with Logan Killicks is a complete failure for Janie. She doesn't find the true love, the freedom and the happiness she experiences under the pear tree. "Vision of Logan Killicks was desecrating the pear tree, but Janie didn't know how to tell Nanny that" (TE, 14).

Janie comes to Nanny to ask for help in her troubled marriage. She says, "Ah wants things sweet wid mah marriage lak when you sit under a pear tree and think. Ah. .." (TE, 24) She wants the same images of bees, blooming, freedom, emotions in marriage. She, instead, experiences a controlling husband and lives in harsh reality.

Bees have often been viewed as brave, industrious, clean, politically harmonious, and aesthetically gifted. These qualities provide extensive examples for symbolic representation. The bee represents perfect community and strongly symbolizes Janie's spirit and wisdom. The feel of the season, springtime, which Hurston implies in different instances of Janie's life, symbolizes the fruitful, positive, optimistic, and happy experience she hopes to have with Joe. ${ }^{11}$ It is on that special day, the day she runs away with Joe that she reunites with nature: "From now on until death she was going to have flower dust and springtime sprinkled over everything. A bee for her bloom."(TE, 32)

Words for nature recur from now on, both in their negative and positive connotations. For example: Janie and Joe go to a place named" Green Cove Springs" to get married. These three words are in harmony with what Janie thought about this marriage. She wanted blooming, hope, and good change. She escapes from Logan to reach far-off horizons and to experience a better life. Green and springs connote happiness. Following these lines, the narrator tells us that while they are happy after marriage and they sit on the house porch, they see" sun plunge into the same crack in the earth from

\footnotetext{
${ }^{9}$ Kalina Saraiva de Lima, "Love is Lak de Sea": Figurative Language in Zora Neale Hurston's Their Eyes Were

Watching God, diss. (East Tennessee State University United States, 2002) 21.

${ }^{10}$ Saraiva de Lima, 21.

${ }^{11}$ Saraiva de Lima, 23-24.
} 
which the night emerged." (TE, 33) This can be interpreted as a threatening image suggesting that from the same source comes both happiness and sadness.

Another incident that shows how much Janie cares about nature is the mule story. Everybody in the town laughs at the mule and some of them intentionally make the poor brute angry, but Janie pities the poor animal and protests silently against the cruel behavior of the town's people. In western tradition, "Historically ... women were positioned in between man and other animals, so that women, and especially women of color, were traditionally viewed in Western culture as neither man nor beast."12 This means, animals can be exploited by human beings just as women can be exploited by men.

Not only her relationship to other members of the community, but also her relationship with her husband is described in terms of nature images and words. The relationship between Janie and Jody turns out to be a shadowy one:" The bed was no longer a daisy-field for her and Joe to play in. It was a place where she went and laid down when she was sleepy and tired. She wasn't petal-open anymore with him. "(TE, 71) Janie understands that there will be no blossoming to her living with Joe. Since she mentions petal-open, which refers to flower image, we can interpret that this flower is oppressed and robbed of its chance to bloom. So Janie understands she cannot expect any blooming from her marriage with Jody, and as days pass by it becomes clearer that their relationship is sterile.

From the elements of nature, the one that recurs frequently all through the novel is the tree. Many different kinds of trees are mentioned, beginning with the pear tree under which Janie finds all her feelings and emotions. The pear tree reconnects Janie to the earth. The first stage of Janie's growth begins with the pear tree and as a tree begins with a seed and grows to be a tree, Janie" grows psychologically - cultivating her identity intellectually, cultivating her voice individually, and cultivating her relationship with her body both sexually and emotionally." 13 The narrator tells us that, "She was seeking confirmation of the voice and vision, and everywhere she found and acknowledged answers. A personal answer for all other creations except herself. She felt an answer seeking her, but where? When? How?" (TE, 11)

But in her first attempt to translate the language of the trees, she fails, and the most important reason for this is that she tries to find love elsewhere. In other words she seeks external love and misses the internal, fulfilling love. That's why she kisses Johnny Taylor at the gate of Nanny and this image leads to consequent failures.

The men prove to be inadequate partners for Janie because they are not positively connected to the trees or conversant in their language and thus do not enhance her existence. Amidst her search for self, the men become mere substitutes for Janie's unrefined joy, providing artificial answers for the questions of completeness that she asks. Just as the tree sheds its leaves in preparation for its season of renewal, Janie must shed each of her partners in order to enter her season of self-cultivated fruitfulness. ${ }^{14}$

She experiences what life should be like to her. It arouses her fantasies of love and passion. She is completely overwhelmed by this feeling. Hurston's use of the tree as a place where Janie experiences overwhelming feelings is significant as a reference to Janie's search for identity. Under the pear tree, her sexuality is defined and understood. In nature, her ideas of marriage arise like the marriage of the bee and the bloom. These have sexual as well as spiritual connotations for her. That is the secret of nature for Janie. The marriage in nature is not one dimensional; it is the marriage of the secular and the spiritual.

Janie looks to nature as a model of love relationship. Although her first two marriages didn't live up to her expectations, her third marriage is mostly fulfilling:

[h] looked like the love thoughts of women. He could be a bee to a blossom - a pear tree blossom in the spring. He seemed to be crushing scent out of the world with his footsteps. Crushing aromatic herbs with every step he took. Spices hung about him. He was a glance from God. (TE, 106)

Finally, what remains of Tea Cake are seeds. These seeds remind Janie of Tea Cake and reconnect her to the land. Somehow, her memories come to life when she plants those seeds. This makes Tea Cake to gain immortality by both being in her memory and by the seeds being planted.

The seeds reminded Janie of Tea Cake more than anything else because he was always planting things. She had noticed them on the kitchen shelf when she came home from the funeral and had put them in her breast pocket. Now that she was home, she meant to plant them for remembrance. (TE, 191)

So, Janie can find nature like love in her third marriage. Here, she identifies Tea Cake with the bee and herself to the blossom. She refers to the pear tree in a few other pages and as the narrator clarifies, she identifies herself as the pear tree as if this tree gives her strength." Oh to be a pear tree- any tree in bloom! With kissing bees singing of the

\footnotetext{
${ }^{12}$ Deborah, L. Madsen, Feminist Theory and Literary Practice (London: Pluto Press, 2000)132.

13 Vivi J. Dabee, The Summons to Behold a Revelation: Femininity and Foliage in Zora Neale Hurston's Their Eyes Were Watching God. diss. (The University of Manitoba, 2008. Ottawa: 2008)11.

${ }^{14}$ Dabee, 13.
} 
beginning of the world! She was sixteen. She had glossy leaves and bursting buds and she wanted to struggle with life but it seemed to elude her." (TE, 11)

\section{Conclusion}

Janie identifies herself with nature. Eco-feminism has many answers for the why of this identification. Based on the dual western system of thought, culture is superior to nature and men are superior to women, so it's very natural that women feel identical with nature. Both women and nature are oppressed by the patriarchal system of thought and technologies. So women are dragged to nature and what happens is a transformation which is at the level of consciousness and worldview. ${ }^{15}$

There can be a lot of interpretations based on the relationship between Janie and the pear tree. From a psychological viewpoint and if we wish to apply Freudian observations, Janie moves from "an imaginary plenitude to a region of lack or desire, the very lack that sets the symbolic field in motion." ${ }^{16}$ Here, this imaginary plenitude is what exactly happens to Janie under the pear tree; and when Nanny marries her off to Logan, she enters the symbolic field. This lack and desire in Janie can best be represented in her kiss behind the gates of her house while being watched by Nanny. According to this theory, women go to the symbolic field to search for satisfaction. This search is in vain, because they can never find plenitude. Janie seeks refuge in men beginning with Logan and then Joe. She finds true satisfaction in herself in the end. So the image of the pear tree acts as an imaginary plenitude.

\section{References}

Butler, Judith. Gender Trouble: Feminism and the Subversion of Identity. New York: Routledge, 1999.

Connel, Raewyn. Gender; Short Introductions. Cambridge: Polity Press, 2009

Dabee, Vivi J. The Summons to Behold a Revelation: Femininity and Foliage in Zora Neale Hurston's Their Eyes Were Watching God. Diss. The University of Manitoba, 2008. Ottawa: 2008.

Glover, David, and Cora Kaplan. Genders. New York: Routledge, 2000.

Hurston, Zora Neal. Their Eyes Were Watching God. New York: Perennial Classics, 1990.

Madsen, Deborah L. Feminist Theory and Literary Practice. London: Pluto Press, 2000.

McAfee, Noëlle. Julia Kristeva. .New York: Routledge, 2004.

Saraiva de Lima, Kalina . "Love is Lak de Sea": Figurative Language in Zora Neale Hurston's Their Eyes Were Watching God.Diss. East Tennessee State University, 2002. North Zeeb Road: ProQuest Information and Learning Company, 2002.

\footnotetext{
${ }^{15}$ See also Madsen, 122-151.

16 Noelle McAfee, Julia Kristeva (New York: Routledge, 2004) 96. The pear tree can be the plentitude for Janie. According to Julia Kristeva, "women are positioned as beings constituted by a lack (imagined castration) that propels them into the symbolic realm in search, however vain, of satisfaction. Imagined castration forces women to leave the imaginary realm of plentitude for the social-symbolic order." (97) In Janie's case this symbolic order can be the world of men in which she refuges. See Also Richard J. Lane, Fifty Key Literary Theorist (New York: Routledge, 2006)187-192.
} 